Učinak količine i tipa dušičnoga gnojiva na agronomska svojstva duhana tipa virdžinija

Effect of nitrogen fertilization rate and type of nitrogen fertilizer on agronomic and morphological traits of flue-cured tobacco

Budimir, A., Svitlica, B., Kiš, D., Lovrić, A., Šarčević, H.

Poljoprivreda/Agriculture

ISSN: 1848-8080 (Online)

ISSN: 1330-7142 (Print)

http://dx.doi.org/10.18047/poljo.25.2.2

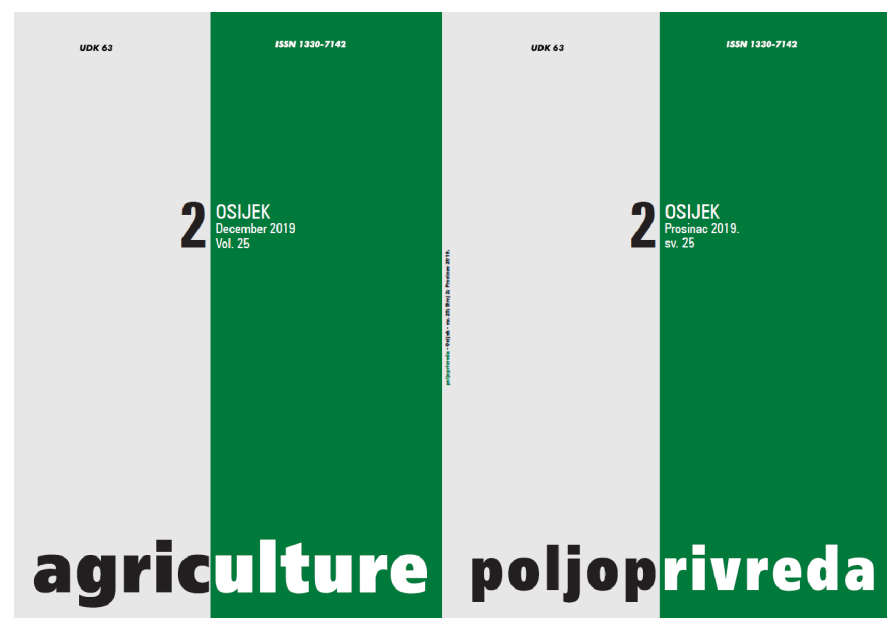

Fakultet agrobiotehničkih znanosti Osijek, Poljoprivredni institut Osijek

Faculty of Agrobiotechnical Sciences Osijek, Agricultural Institute Osijek 
ISSN 1330-7142

$U D K=633.71: 631.84$

DOI: $10.18047 /$ poljo.25.2.2

\section{UČINAK KOLIČINE I TIPA DUŠIČNOGA GNOJIVA NA AGRONOMSKA SVOJSTVA DUHANA TIPA VIRDŽINIJA}

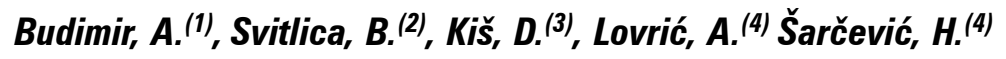

Izvorni znanstveni članak

Original scientific paper

\section{SAŽETAK}

Cilj ovoga rada bio je utvrditi učinak gnojidbe dušikom (N) od 30 odnosno od $45 \mathrm{~kg} / \mathrm{ha}$, kao i trima komercijalnim dušičnim gnojivima, CaNO3 (15\% N), KAN (27\% N) i YaraMilaTM Cropcare (8:11:23), na agronomska svojstva: prinos, cijenu $i$ vrijednost suhoga lista, kao $i$ na šest morfoloških svojstava duhana tipa virdžinija. U poljski pokus, proveden u četiri okoline, bila su uključena tri hrvatska kultivara duhana. Gnojidba dušikom imala je signifikantan učinak samo na komponente prinosa: duljinu, širinu i površinu 9. lista, čije su vrijednosti kod gnojidbe $s 45 \mathrm{~kg} \mathrm{~N} / \mathrm{ha}$ bile za 2,2; 3,5 odnosno 5,8\% veće u odnosu na gnojidbu $s 30 \mathrm{~kg} \mathrm{~N} / \mathrm{ha}$. Tip korištenoga dušičnog gnojiva nije imao signifikantan učinak niti na jedno ispitivano svojstvo. Uzorak korelacija između morfoloških i gospodarskih svojstava bio je pod utjecajem okoline, kao i razine gnojidbe. lako nije utvrđen učinak gnojidbe na gospodarska svojstva, signifikantno povećanje komponenata prinosa kod gnojidbe s $45 \mathrm{~kg} \mathrm{~N} / \mathrm{ha}$, u usporedbi s $30 \mathrm{~kg} \mathrm{~N} / \mathrm{ha}$, upućuje na višu razinu gnojidbe kao jamstvo osiguranja visokih i stabilnih prinosa te kvalitete osušenoga lista.

Ključne riječi: duhan tipa virdžinija, dušik, gnojidba, prinos, kvaliteta

UVOD

Mineralna gnojidba duhana tipa virdžinija trebala bi osigurati dostatne količine hranjivih tvari, osobito makrohraniva, dušika, fosfora i kalija, kako bi bio postignut visok prinos i kvaliteta suhoga lista uz što niže troškove proizvodnje. Dušik je ključan za postizanje visokih prinosa visokokvalitetnoga suhog lista, pri čemu optimalne količine dušičnoga gnojiva u određenim agroekološkim uvjetima variraju unutar relativno uskih granica (Hawks i Collins, 1983.). Nedovoljne količine raspoloživoga dušika tijekom vegetativnoga rasta duhana sve do pune cvatnje mogu rezultirati smanjenjem prinosa. $S$ druge strane, prekomjerna gnojidba dušikom nakon cvatnje može smanjiti kvalitetu suhoga lista, a time i njegovu komercijalnu vrijednost, može otežati mehaničku berbu i sušenje zagađenje tla i podzemnih voda te povećati razinu za zdravlje štetnih sastojaka u listu, kao što su nitrati i nitriti (Marchetti i sur., 2006.). Sisson i sur. (1991.) utvrdili su da su superiorni prinos i kvaliteta novih kultivara duhana, u odnosu na starije, popraćene poboljšanom učinkovitošću korištenja dušika. Također, ukazali su na mogućnost razvoja novih kultivara prilagođenih tlima različite plodnosti i zaliha dušika.

(1) Doc. dr. sc. Ankica Budimir (ana_budimir@bat.com) - British American Tobacco, Zagrebačka 52, 34340 Kutjevo, Hrvatska, (2) Dr. sc. Brankica Svitlica - Veleučilište u Požegi, Slavonska 6, 34000 Požega, Hrvatska, (3) Prof. dr. sc. Darko Kiš - Sveučilište Josipa Jurja Strossmayera, Fakultet agrobiotehničkih znanosti Osijek, Vladimira Preloga 1,31000 Osijek, Hrvatska, (4) Dr. sc. Ana Lovrić, prof. dr. sc. Hrvoje Šarčević - Sveučilište u Zagrebu, Agronomski fakultet, Svetošimunska cesta 25, 10000 Zagreb, Hrvatska 
0 boljoj prilagođenosti novih kultivara duhana tlima različite plodnosti i zaliha dušika u odnosu na starije izvijestili su i Šarčević i sur. (2013.), koji su na osnovi trogodišnjega pokusa provedenog na različitim tipovima tala utvrdili veću stabilnost prinosa kod novijih kultivara.

Eksperimentalni rezultati proučavanja učinka dušika na prinos i kvalitetu duhana (Wan i Salbiah, 1989.; Sisson i sur., 1991.; Cristanini, 2006.; Marchetti i sur., 2006.; Budimir i sur., 2008.; Bukan i sur., 2013.) su pokazali da osnovne potrebne količine dušika mogu varirati od $30 \mathrm{~kg} \mathrm{~N} / \mathrm{ha}$ do $120 \mathrm{~kg} \mathrm{~N} / \mathrm{ha}$, ovisno o kultivaru i agroekološkim uvjetima. Na pjeskovitoj ilovači se često preporučuje primjena dodatnoga dušika (N) kako bi se nadoknadio dušik koji je izgubljen rano u sezoni rasta zbog ispiranja (Marchetti i sur., 2006.). Wan i Salbiah (1989.) su proveli dvogodišnje istraživanje na lokaciji Kelanta (Malezija) na dva lokalna kultivara duhana uz primjenu 40 do $120 \mathrm{~kg} \mathrm{~N} / \mathrm{ha}$. U prvoj godini istraživanja prinos se signifikantno povećavao povećanjem doze do $80 \mathrm{~kg} \mathrm{~N} / \mathrm{ha}$, dok u drugoj godini nije bilo signifikantnih razlika u prinosu između doza dušika. Marchetti i sur. (2006.) su u sjevernoj Italiji uzgajali kultivar K326 kod pet razina gnojidbe dušikom $(0,20$, 40,60 , i $80 \mathrm{~kg} \mathrm{~N} / \mathrm{ha}$ ) i utvrdili signifikantan porast prinosa suhoga lista s povećanom dozom dušika u jednoj vegetacijskoj sezoni. Međutim, u drugoj vegetacijskoj sezoni $40 \mathrm{~kg} \mathrm{~N} / \mathrm{ha}$ bilo je dostatno za postizanje optimalnoga prinosa duhana. $\mathrm{S}$ druge strane, Cristanini (2006.) za uzgoj duhana u uvjetima sjeverne Italije preporučuje znatno veće doze dušika, koje se mogu kretati u rasponu od 80 do $120 \mathrm{~kg} \mathrm{~N} / \mathrm{ha}$. Zhang i sur. (2010.) proučavali su učinak dušične gnojidbe na tri kultivara duhana u uvjetima Narodne Republike Kine i utvrdili bolju kvalitetu i veću vrijednost suhoga lista kod gnojidbe od $45 \mathrm{~kg} \mathrm{~N} / \mathrm{ha}$ u odnosu na gnojidbu od 60 i 75 $\mathrm{kg} \mathrm{N} / \mathrm{ha}$. Drake i sur. (2017.) su u dvogodišnjem pokusu postavljenom na pet lokacija u Sjevernoj Karolini (SAD) ispitali učinak gnojidbe dušikom na gospodarska svojstva duhana, primijenjene u količini od 75, 100 i 125\% preporučenih doza, koje su, ovisno o lokaciji, varirale od 74 do $80 \mathrm{~kg} \mathrm{~N} / \mathrm{ha}$. Ni na jednoj lokaciji nije utvrđen signifikantni učinak doze dušika na prinos, cijenu niti na vrijednost. Autori su zaključili da su iznadprosječne količine oborina $u$ ispitivanim godinama imale signifikantan utjecaj na dobivene rezultate.

Budimir i sur. (2008.) proveli su trogodišnje istraživanje $s$ tri hrvatska kultivara duhana i dvije razine gnojidbe dušikom (40 i $60 \mathrm{~kg} \mathrm{~N} / \mathrm{ha}$ ) na lokacijama Kutjevo i Virovitica, s tlima u tipu glinaste ilovače odnosno pjeskovite ilovače. Uspoređujući dvije lokacije, koje su reprezentativne za glavno uzgojno područje duhana u Hrvatskoj, autori su utvrdili signifikantno veći prinos i vrijednost na pjeskovitoj ilovači u Virovitici. Između dviju razina gnojidbe nisu utvrđene signifikantne razlike za navedena svojstva, osim u 2001. godini, kada je viša razina gnojidbe rezultirala većim prinosom, ali ne i većom vrijednošću proizvodnje. U kasnijem istraživanju koje su proveli Bukan i sur. (2013.) s tri hrvatska i jednim američkim kultivarom duhana, koji su uzgajani kod dvije razine gnojidbe (30 i $60 \mathrm{~kg} \mathrm{~N} / \mathrm{ha}$ ) na lokacijama Kutjevo i Virovitica u 2010. i 2011. godini, također je utvrđeno povećanje prinosa i vrijednosti kod više razine gnojidbe samo u jednoj godini istraživanja.

Prikazane domaće i strane studije, vezane uz gnojidbene pokuse $s$ duhanom, pokazale su postojanje velikoga utjecaja lokacije (tipa tla) i vremenskih prilika (vegetacijske sezone) na rezultate. Uzevši u obzir i postojanje interakcija između gnojidbe dušikom, lokacije, uzgojne sezone i genotipa, potrebna su dodatna istraživanja, koja će doprinijeti sigurnijim preporukama za optimalnu gnojidbu duhana dušikom. Pokusi provedeni na hrvatskom sortimentu duhana u uvjetima sjeverozapadne $\mathrm{i}$ istočne Hrvatske, u kojima je testiran učinak povećane doze od $60 \mathrm{~kg} \mathrm{~N} / \mathrm{ha}$ vs. $40 \mathrm{~kg} \mathrm{~N} / \mathrm{ha}$ (Budimir i sur. 2008) odnosno $60 \mathrm{~kg} \mathrm{~N} / \mathrm{ha}$ vs. $30 \mathrm{~kg} \mathrm{~N} /$ ha (Bukan i sur. 2013.) u ukupno deset okolina, pokazali su pozitivan učinak većih doza dušika na vrijednost (kn/ha) samo u dvije okoline, u Virovitici 2010. i u Kutjevu 2010 (Bukan i sur. 2013.). Budući da navedeno povećanje vrijednosti, ostvareno $\mathrm{s}$ dvostruko većom dozom dušika $(60 \mathrm{~kg} / \mathrm{ha})$ u odnosu na referentnu količinu $(30 \mathrm{~kg} / \mathrm{ha})$, znači ne samo dvostruko veći trošak nego i moguće gubitke kroz ispiranje dušika u slučaju prekomjernih oborina tijekom vegetacije, potrebno je utvrditi učinak umjerenoga povećanja doze dušika na gospodarska svojstva duhana.

Stoga je prvi cilj ovoga rada bio utvrditi učinak niske (30 kg N/ha) i umjerene (45 kg N/ha) gnojidbe dušikom na prinos, cijenu i vrijednost osušenoga lista duhana. Drugi cilj je bio utvrditi učinak različitih tipova dušičnih gnojiva koja su na tržištu na navedena gospodarska svojstva.

\section{MATERIJAL I METODE}

Trofaktorijalni poljski pokus koji je uključivao tri vrste dušičnoga gnojiva (YaraMilla ${ }^{\mathrm{TM}}$ Cropcare 8:11:23; KAN 27\% i $\mathrm{CaNO}_{3} 15 \% \mathrm{~N}$ ), dvije razine gnojidbe dušikom ( $30 \mathrm{~kg} \mathrm{~N} / \mathrm{ha}$ i $45 \mathrm{~kg} \mathrm{~N} / \mathrm{ha}$ ) i tri virdžinijska kultivara duhana (DH27, DH36 i DH17) postavljen je u četiri ponavljanja na lokaciji Virovitica u 2015., 2016. i 2017. godini te na lokaciji Kutjevo u 2017. godini. Pokusi u 2016. godini bili su uništeni vremenskim nepogodama (tuča, kiša), pri čemu je došlo do destrukcije duhana. Eksperimentalni dizajn u svima trima okolinama (kombinacija lokacija - godina) bio je slučajni blok-raspored s faktorijalnom kombinacijom dviju razina dušika, triju vrsta gnojiva, i triju kultivara. Ispitivani virdžinijski kultivari su tri najzastupljenija komercijalna kultivara u proizvodnji u Hrvatskoj. Tlo na lokaciji Kutjevo jest glinasta ilovača, teže i hladnije, sa srednjim sadržajem organske tvari, dok 
je na lokaciji Virovitica tlo tipa pjeskovite ilovače, lakše i toplije, s niskim sadržajem organske tvari (Budimir i sur., 2008.; Bukan i sur., 2013.). Prijesadnice duhana su proizvedene hidroponski. Ručna sadnja pokusa u svim godinama je obavljena početkom svibnja (04.05.2015., 06.05.2016. i 09.05.2017., obično prvoga tjedna, ovisno 0 vremenskim uvjetima) $\mathrm{u}$ troredne parcelice $\mathrm{s}$ međurednim razmakom od $100 \mathrm{~cm}$ i $50 \mathrm{~cm}$. U svakom redu su posađene 22 biljke. Osnovna gnojidba je obavljena, kao što je uobičajeno u komercijalnoj proizvodnji, prije izradbe gredica s PK gnojivom (0:5:30) u količini od 500 $\mathrm{kg} / \mathrm{ha}$, pri čemu je ukupno dodano $25 \mathrm{~kg} /$ ha $\mathrm{P}_{2} \mathrm{O}_{5}$ i 150 $\mathrm{kg} / \mathrm{ha} \mathrm{K} \mathrm{K}_{2} \mathrm{O}$.

Za zaštitu protiv zemljišnih insekata (sovice i žičnjaka) korišten je Dursban u količini $6 \mathrm{I} /$ ha (unesen u zemlju), a za zaštitu od korova korišten je Stomp (a.i. Pednimethalin 3,0 $\mathrm{l} / \mathrm{ha}$ ) u kombinaciji s Kalifom (a.i Clomazon 0,6 l/ha) po površini. Prihrana dušikom s ukupnom količinom od $30 \mathrm{~kg}$ odnosno $45 \mathrm{~kg} \mathrm{~N} / \mathrm{ha}$ obavljena je u dva navrata, zajedno s kultivacijom prije sadnje odnosno u prvoj kultivaciji nakon sadnje korištenjem triju vrsta gnojiva (YaraMilla 8:11:23; KAN 27\%N; $\mathrm{CaNO}_{3} 15 \%$ N). Kultivacija i unošenje gnojiva provedeno je deset do četrnaest dana nakon sadnje, nakon ukorjenjivanja duhana. Mjere dodatne njege usjeva uključivale su po potrebi kultivacije i ručna okapanja ovisno o zakorovljenosti i zbijenosti tla. U vegetaciji je na 10 slučajnih biljaka u srednjem redu svake parcelice izmjerena visina biljke do cvata $(\mathrm{cm})$, broj listova te širina $(\mathrm{cm})$ i duljina $(\mathrm{cm}) 9$. lista. Površinu 9. lista $\left(\mathrm{cm}^{2}\right)$ izračunata je množenjem duljine lista, širine lista i koeficijenta 0.6345 prema Tsou (1972.). Za svaku parcelicu izračunat je i omjer širine i duljine lista. Berba je obavljena ručno u nekoliko rokova, i u prosjeku su brana 2-3 lista po roku ovisno 0 zrelosti. Broj berba varirao je od godine do godine: u 2015. godini bilo je šest berba (01.07.2015., 04.08.2015., 17.08.2015., 26.09.2015., 07.10.2015. i 15.10.2015.). Broj berba u 2017. iznosio je ukupno sedam (12.07.2107., 04.08.2017., 01.09.2017., 22.09.2017., 12.10.2017., 21.10.2017. i 28.10.2017.). Listovi su prije sušenja vezani u snopiće i obilježeni etiketom na kojoj se nalazio datum berbe i oznaka sorte. Nakon sušenja, koje je trajalo od 120-140 sati ovisno o zrelosti duhana, kultivaru i vlažnosti, listovi su izvađeni iz sušnice i otkupljeni prema klasama (1-6). Prinos je izračunat kao zbroj odvaga suhoga lista sviju berba po parcelici i izražen u kg/ha. Otkupnu cijenu svake poje- dinačne berbe ustanovio je na osnovi klase službeni otkupljivač. Cijena suhoga lista $(\mathrm{kn} / \mathrm{kg})$ je za svaku pokusnu parcelicu izračunata iz prosječne otkupne cijene i količine svake klase. Vrijednost je izračunata množenjem cijene i prinosa svake pokusne parcelice i izražena u $\mathrm{kn} / \mathrm{ha}$. Za sva ispitivana svojstva provedena je kombinirana analiza varijance kroz okoline, pri čemu su svi faktori smatrani fiksnima. Srednje vrijednosti faktora su uspoređene pomoću Fisherova LSD-testa, a povezanost između svojstava utvrđena je pomoću Pearsonovih korelacijskih koeficijenata. Sve analize provedene su pomoću statističkoga programa ADEL-R (Pacheco i sur., 2017.).

\section{REZULTATI I RASPRAVA}

Kombinirana analiza varijance (Tablica 1) pokazala je signifikantan učinak okoline (E) na sva svojstva, količine dodanoga dušika (N) na duljinu, širinu i površinu 9. lista te učinak genotipa na sva svojstva, osim na površinu 9. lista. Vrsta korištenoga dušičnog gnojiva (F) nije imala signifikantan učinak niti na jedno ispitivano svojstvo. Signifikantna interakcija $E \times G$ utvrđena je za prinos, cijenu, vrijednost, širinu i površinu 9 . lista te za omjer širine i duljine lista, signifikantna interakcija $F \times$ $G$ za broj listova, dok ostale interakcije nisu bile signifikantne. Drake i sur. (2017.) nisu utvrdili signifikantan učinak gnojidbe dušikom na prinos, cijenu i vrijednost lista duhana u uvjetima u Sjevernoj Karolini (SAD), što je u skladu s našim rezultatima. $S$ druge strane, učinak različitih količina dušika na prinos lista u višegodišnjim istraživanjima, koje su proveli Marchetti i sur. (2006.), Zhang i sur (2010.) te Budimir i sur. (2008) u uvjetima Italije, Narodne Republike Kine odnosno Hrvatske, bio je signifikantan samo u jednoj godini istraživanja. Slično su Wan i Salbiah (1989.) u uvjetima Malezije te Bukan i sur. (2013.) u uvjetima Hrvatske utvrdili utjecaj gnojidbe dušikom kako na prinos tako i na vrijednost samo u jednoj godini istraživanja. Za razliku od našega istraživanja, u kojem nije utvrđena signifikantna interakcija količine dodanoga dušika niti s jednim faktorom, Wan i Salbiah (1989.) su izvijestili o signifikantnoj interakciji količine dušika s lokacijom za cijenu odnosno kultivarom za vrijednost. Slično su i Budimir i sur. (2008) utvrdili signifikantnu interakciju dušika s lokacijom za cijenu i vrijednost, a Bukan i sur., (2013.) signifikantnu interakciju dušika s lokacijom za cijenu, odnosno s lokacijom i kultivarom za prinos. 
Tablica 1. Analiza varijance (signifikantnost $F$ vrijednosti) za devet svojstava virdžinijskoga duhana

Table 1. Analysis of variance (significance of $F$ value) for nine traits of flue-cured tobacco

\begin{tabular}{|c|c|c|c|c|c|c|c|c|c|c|}
\hline \multirow[b]{2}{*}{$\begin{array}{l}\text { Učinak } \\
\text { Effect }\end{array}$} & \multirow[b]{2}{*}{ Df } & \multicolumn{9}{|c|}{ Svojstvo / Trait } \\
\hline & & 을 흘 & 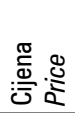 & 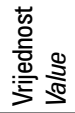 & $\stackrel{m}{>}$ & $\overrightarrow{\bar{\omega}} \dot{2}$ & के & क) & চా চ & $\stackrel{0}{\infty} \underset{s}{S}$ \\
\hline Okolina / Environment (E) & 2 & $* *$ & $* *$ & $* *$ & $* *$ & $* *$ & $* *$ & $* *$ & $* *$ & $* *$ \\
\hline Dušik / Nitrogen (N) & 1 & ns & ns & ns & ns & ns & $*$ & $* *$ & ** & ns \\
\hline Gnojivo / Fertilazer (F) & 2 & ns & ns & ns & ns & ns & ns & ns & ns & ns \\
\hline Genotip / Genotype (G) & 2 & $* *$ & $* *$ & $* *$ & $* *$ & $* *$ & $* *$ & $* *$ & ns & ** \\
\hline $\mathrm{E} \times \mathrm{N}$ & 2 & ns & ns & ns & ns & ns & ns & ns & ns & ns \\
\hline$E \times F$ & 4 & ns & ns & ns & ns & ns & ns & ns & ns & ns \\
\hline $\mathrm{E} \times \mathrm{G}$ & 4 & $* *$ & $* *$ & $* *$ & ns & ns & ns & $* *$ & $* *$ & * \\
\hline $\mathrm{N} \times \mathrm{F}$ & 2 & ns & ns & ns & ns & ns & ns & ns & ns & ns \\
\hline $\mathrm{N} \times \mathrm{G}$ & 2 & ns & ns & ns & ns & ns & ns & ns & ns & ns \\
\hline$F \times G$ & 4 & ns & ns & ns & ns & ${ }^{*}$ & ns & ns & ns & ns \\
\hline $\mathrm{E} \times \mathrm{N} \times \mathrm{F}$ & 4 & ns & ns & ns & ns & ns & ns & ns & ns & ns \\
\hline $\mathrm{E} \times \mathrm{N} \times \mathrm{G}$ & 4 & ns & ns & ns & ns & ns & ns & ns & ns & ns \\
\hline $\mathrm{E} \times \mathrm{F} \times \mathrm{G}$ & 8 & ns & $\mathrm{ns}$ & ns & ns & ns & ns & ns & ns & $\mathrm{ns}$ \\
\hline $\mathrm{N} \times \mathrm{F} \times \mathrm{G}$ & 4 & ns & ns & ns & ns & ns & ns & ns & ns & ns \\
\hline $\mathrm{E} \times \mathrm{N} \times \mathrm{F} \times \mathrm{G}$ & 8 & ns & ns & ns & ns & ns & ns & ns & ns & ns \\
\hline
\end{tabular}

Df - stupnjevi slobode; ${ }^{*}$ signifikantno kod $\mathrm{P}<0.05 ;{ }^{* *}$ signifikantno kod $\mathrm{P}<0.01$; ns - nije signifikantno; VB - visina biljke; Br.L - broj listova; D9L - duljina 9. lista; ŠgL - širina 9. lista; P9L - površina 9. lista; $\breve{S} / D$ - omjer širine i duljine lista

$D f$ - degrees of freedom; * significant at $P<0.05 ;{ }^{*}$ significant at $P<0.01 ;$ ns - not significant; $P H$ - plant height; No.L - number of leaves; $L 9 L$ - length of the $g^{\text {th }}$ leaf; WgL - width of the $9^{\text {th }}$ leaf; $A 9 L$ - area of the $9^{\text {th }}$ leaf; W/L -width to length ratio

U Tablici 2 prikazani su prinos, cijena i vrijednost suhog lista za tri kultivara virdžinijskoga duhana uzgajana u trima okolinama. Okoline kao i kultivari signifikantno su se razlikovali u sva tri svojstva. U Virovitici 2015. su prinos i cijena i vrijednost bili signifikantno veći u odnosu na Kutjevo 2017. i Viroviticu 2017. U prosjeku za sve tri okoline kultivari DH36 i DH27 ostvarili su signifikantno veći prinos nego kultivar DH17. Najniža cijena u svim lokacijama okolinama utvrđena je kod kultivara DH17, dok je najveća cijena na svim lokacijama utvrđena kod kultivara DH27. U prosjeku za sve tri okoline najveću vrijednost ostvario kultivar DH27, zatim DH36, a najmanju kultivar DH17.
U Tablici 3 prikazani su prosjeci za devet svojstva kod niže ( $30 \mathrm{~kg} \mathrm{~N} / \mathrm{ha})$ i više $(45 \mathrm{~kg} \mathrm{~N} / \mathrm{ha})$ razine gnojidbe, kao i apsolutna i relativna razlika između gnojidaba. Gnojidba dušikom je imala signifikantan učinak samo na duljinu, širinu i površinu 9. lista, čije su vrijednosti kod više gnojidbe bile za 2,2; 3,5 odnosno $5,8 \%$ veće u odnosu na nižu gnojidbu. Izostanak učinka gnojidbe dušikom na prinos, cijenu i vrijednost u našem istraživanju u skladu je s rezultatima Drakea i sur. (2017.), koji također nisu utvrdili signifikantni učinak dušika primijenjenih u količini od 75, 100 i $125 \%$ preporučenih doza niti na jedno spomenuto svojstvo.

Tablica 2. Prinos (kg/ha), cijena (kn/kg) i vrijednost (kn/ha) suhog lista za tri kultivara virdžinijskoga duhana uzgajana u-trima okolinama

Table 2. Yield ( $\mathrm{kg} / \mathrm{ha})$, price $(\mathrm{kn} / \mathrm{kg})$ and value $(\mathrm{kn} / \mathrm{ha})$ of cured leaf for three flue cured tobacco cultivars grown in three environments

\begin{tabular}{|c|c|c|c|c|}
\hline \multirow{3}{*}{$\begin{array}{l}\text { Okolina } \\
\text { Environment }\end{array}$} & \multicolumn{4}{|c|}{ Kultivar / Cultivar } \\
\hline & $\mathrm{DH} 17$ & $\mathrm{DH} 27$ & $\mathrm{DH} 36$ & Prosjek / Mean \\
\hline & \multicolumn{4}{|c|}{ Prinos / Yield (kg/ha) } \\
\hline Virovitica 2015 & 3821 & 4053 & 3927 & $3934 a^{\#}$ \\
\hline Kutjevo 2017 & 2479 & 3211 & 3298 & $2996 \mathrm{c}$ \\
\hline Virovitica 2017 & 2558 & 2688 & 2525 & $2590 \mathrm{~b}$ \\
\hline \multirow[t]{2}{*}{ Prosjek / Mean } & $2953 \mathrm{~b}$ & 3317 a & $3250 \mathrm{a}$ & \\
\hline & \multicolumn{4}{|c|}{ Cijena / Price $(\mathrm{kn} / \mathrm{kg})$} \\
\hline Virovitica 2015 & 16,02 & 16,48 & 16,30 & 16,26 a \\
\hline Kutjevo 2017 & 10,44 & 11,90 & 11,44 & $11,26 \mathrm{c}$ \\
\hline Virovitica 2017 & 12,14 & 12,83 & 12,36 & $12,44 \mathrm{~b}$ \\
\hline \multirow[t]{2}{*}{ Prosjek / Mean } & $12,87 \mathrm{c}$ & $13,73 \mathrm{a}$ & $13,37 \mathrm{~b}$ & \\
\hline & \multicolumn{4}{|c|}{ Vrijednost / Value (kn/ha) } \\
\hline Virovitica 2015 & 61206 & 66762 & 63998 & 63989 a \\
\hline Kutjevo 2017 & 25906 & 38191 & 37790 & 33962 b \\
\hline Virovitica 2017 & 31013 & 34522 & 31148 & $32228 \mathrm{~b}$ \\
\hline Prosjek / Mean & $39375 \mathrm{c}$ & $46492 \mathrm{a}$ & $44312 \mathrm{~b}$ & \\
\hline
\end{tabular}

\# a,b,c - različita slova označuju statistički signifikantne razlike između prosjeka okolina odnosno kultivara kod $\mathrm{P}<0.05$ na osnovi Fisherova LSD-testa

${ }^{\#} a, b, c$ - different letters mark statistically significant difference at $P<0.05$ based on Fisher's LSD test 
S druge strane, Wan i Salbiah (1989.), Marchetti i sur. (2006.), Budimir i sur. (2008.) te Bukan i sur. (2013.) dokazali su da optimalne doze dušika variraju ovisno 0 vegetacijskoj sezoni odnosno lokaciji, upućujući na veliki ulogu vremenskih prilika i tipa tla na iskoristivost dodanoga dušika. Bukan i sur. (2013.) su, slično našim rezultatima, izvijestili o signifikantnom povećanju površine 9 . lista kod više doze dušika. Međutim, veća površina 9 . lista u njihovu istraživanju odrazila se na signifikantno povećanje prinosa i vrijednosti, što nije bio slučaj u našem istraživanju.

Tablica 3. Prosječne vrijednosti za devet svojstava kod dvije razine gnojidbe dušikom (N)

Table 3. Means for nine properties at two nitrogen (N) fertilization levels

\begin{tabular}{|c|c|c|c|c|c|}
\hline \multirow{3}{*}{$\begin{array}{l}\text { Svojstvo / Trait } \\
\text { Prinos / Yield (kg/ha) }\end{array}$} & \multicolumn{5}{|c|}{ Gnojidba / Fertilization } \\
\hline & \multirow{2}{*}{$\frac{30 \mathrm{~kg} \mathrm{~N} / \mathrm{ha}}{3125}$} & \multirow{2}{*}{$\begin{array}{c}45 \mathrm{~kg} \mathrm{~N} / \mathrm{ha} \\
3222\end{array}$} & \multicolumn{2}{|c|}{$D(45-30)$} & \multirow{2}{*}{$\begin{array}{l}\mathrm{D} \% \\
3,1\end{array}$} \\
\hline & & & 97 & ns & \\
\hline Cijena / Price (kn/kg) & 13,32 & 13.33 & 0,01 & ns & 0,1 \\
\hline Vrijednost / Value (kn/ha) & 42712 & 44074 & 1362 & ns & 3,2 \\
\hline $\mathrm{VB} / P H(\mathrm{~cm})$ & 99,4 & 101,7 & 2,26 & ns & 2,3 \\
\hline Br.L / No.L & 21,1 & 21,2 & 0,12 & ns & 0,6 \\
\hline $\mathrm{D} 9 \mathrm{~L} / \mathrm{LgL}(\mathrm{cm})$ & 49,5 & 50,6 & 1,10 & $*$ & 2,2 \\
\hline ŠgL / WgL (cm) & 25,2 & 26,1 & 0,88 & $* *$ & 3,5 \\
\hline $\mathrm{P} 9 \mathrm{~L} / A 9 \mathrm{~L}\left(\mathrm{~cm}^{2}\right)$ & 795 & 841 & 46,4 & $* *$ & 5,8 \\
\hline Š/D / W/L & 0,51 & 0,52 & 0,01 & ns & 1,4 \\
\hline
\end{tabular}

$\mathrm{D}(45-30)$ - razlika prosječnih vrijednosti svojstva između više i niže razine gnojidbe; ${ }^{*}$ signifikantno kod $\mathrm{P}<0.05$; ${ }^{* *}$ signifikantno kod $\mathrm{P}<0.01$; ns - nije signifikantno; D\% - razlika prosječnih vrijednosti svojstva između više i niže razine gnojidbe, izražena u postotku niže razine

$D(45-30)$ - difference in mean trait values between higher and lower levels of fertilization; ${ }^{*}$ significant at $P<0.05 ;{ }^{* *}$ significant at $P<0.01 ; n s-n o t$ significant; $D \%$ - difference in mean trait values between higher and lower levels of fertilization expressed as a percentage of the lower level

Iz prikaza korelacija između agronomskih svojstava i prinosa i cijene duhana (Tablica 4) vidljivo je da je prinos na svim lokacijama bio u signifikantnoj pozitivnoj korelaciji s visinom biljke, brojem listova kao i duljinom 9. lista, dok je signifikantna pozitivna korelacija između prinosa i površine 9. lista utvrđena samo na lokaciji Virovitica u 2015. i 2017. godini. Između prinosa i omjera širine i duljine 9. lista utvrđena je signifikantna negativna korelacija samo u Virovitici 2017. U većini slučajeva vrijednosti korelacijskih koeficijenta bile su veće kod više razine gnojidbe (45 kg N/ha). Bukan i sur. (2013) su također izvijestili o pozitivnim korelacijama prinosa i visine biljke te površine 9 . lista, dok je korelacija prinosa i broja listova u njihovu istraživanju u jednoj godini bila pozitivna, a u drugoj negativna. I više drugih autora je izvijestilo o pozitivnim korelacijama prinosa i visine biljke, broja listova, duljine, širine i površine lista (White i sur., 1979.; Maleki i sur., 2011.; Shah i sur., 2016.). Šarčević i sur. (2013.) su proučavali genetski napredak hrvatskih kultivara virdžinijskoga duhana priznatih od 1983. do 2007. i zaključili da je veći prinos kod novijih kultivara povezan s povećanjem broja listova po biljci. Cijena je bila u signifikantnoj pozitivnoj korelaciji s visinom biljke i brojem listova u Virovitici 2015., kao i s visinom biljke i duljinom 9. lista u Kutjevu 2017. te s omjerom širine i duljine 9. lista u Virovitici 2015. i Kutjevu 2017., s većim vrijednostima korelacijskih koeficijenata kod niže razine gnojidbe (30 kg N/ha). Bukan i sur. (2013.) također su utvrdili pozitivnu korelaciju cijene i visine, broja listova i površine 9. lista. U ovome radu je između prinosa i cijene utvrđena signifikantna pozitivna korelacija samo na lokaciji Kutjevo 2017. ( $r=0,76$ i 0,59 za nižu, odnosno višu razinu gnojidbe dušikom). Bukan i sur. (2013.) također su utvrdili pozitivnu korelaciju između cijene i prinosa, koja je također imala manju vrijednost kod više gnojidbe u odnosu na reduciranu gnojidbu dušikom. 
Tablica 4. Pearsonovi korelacijski koeficijenti između sekundarnih agronomskih svojstava i prinosa i cijene virdžinijskoga duhana uzgajanog u trima okolinama (Virovitica 2015., Virovitica 2017. te Kutjevo 2017.) kod dvije razine gnojidbe dušikom (30 i $45 \mathrm{~kg} / \mathrm{ha}$ )

Table 4. Pearson's correlation coefficients between agronomic traits and yield and price of the flue-cured tobacco grown in three environments (Virovitica 2015 and 2017 and Kutjevo 2017) at two nitrogen fertilization rates (30 and $45 \mathrm{~kg} / \mathrm{ha}$ )

\begin{tabular}{|c|c|c|c|c|c|c|c|c|c|c|c|c|c|}
\hline \multirow[t]{2}{*}{ Svojstvo / Trait } & \multirow[b]{2}{*}{$\mathrm{N} \mathrm{kg/ha}$} & \multicolumn{2}{|c|}{ 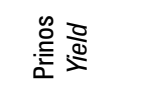 } & \multicolumn{2}{|c|}{ 蹗 } & \multicolumn{2}{|c|}{ 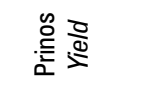 } & \multicolumn{2}{|c|}{ 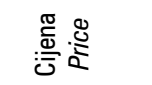 } & \multicolumn{2}{|c|}{ : } & \multicolumn{2}{|c|}{ 苞 } \\
\hline & & \multicolumn{4}{|c|}{ Virovitica 2015} & \multicolumn{4}{|c|}{ Virovitica 2017} & \multicolumn{4}{|c|}{ Kutjevo 2017} \\
\hline VB & 30 & 0,23 & & 0,31 & & 0,53 & $* *$ & 0,37 & $*$ & 0,70 & $* *$ & 0,61 & ** \\
\hline$P H$ & 45 & 0,67 & $* *$ & 0,32 & & 0,63 & $* *$ & 0,20 & & 0,63 & $* *$ & 0,56 & $* *$ \\
\hline Br.L & 30 & 0,36 & * & 0,29 & & 0,30 & & 0,41 & $*$ & 0,24 & & 0,29 & \\
\hline No.L & 45 & 0,59 & $* *$ & 0,26 & & 0,58 & $* *$ & 0,17 & & 0,41 & $*$ & 0,33 & \\
\hline D9L & 30 & 0,65 & $* *$ & 0,29 & & 0,59 & $* *$ & 0,32 & & 0,40 & * & 0,36 & $*$ \\
\hline$L 9 L$ & 45 & 0,59 & $* *$ & 0,11 & & 0,70 & $* *$ & 0,10 & & 0,33 & & 0,20 & \\
\hline ŠgL & 30 & 0,22 & & $-0,08$ & & 0,08 & & 0,15 & & 0,28 & & 0,05 & \\
\hline WIL & 45 & 0,25 & & $-0,11$ & & 0,10 & & $-0,13$ & & 0,09 & & $-0,26$ & \\
\hline P9L & 30 & 0,42 & $*$ & 0,08 & & 0,39 & * & 0,26 & & 0,33 & & 0,17 & \\
\hline$A 9 L$ & 45 & 0,43 & $*$ & 0,00 & & 0,45 & ** & $-0,01$ & & 0,21 & & $-0,09$ & \\
\hline Š/D & 30 & $-0,34$ & & $-0,39$ & $*$ & $-0,51$ & $*$ & $-0,13$ & & 0,05 & & $-0,26$ & \\
\hline$W / L$ & 45 & $-0,33$ & & $-0,26$ & & $-0,70$ & $* *$ & $-0,24$ & & $-0,13$ & & $-0,46$ & $* *$ \\
\hline Prinos & 30 & & & 0,23 & & & & $-0,17$ & & & & 0,76 & ** \\
\hline Yield & 45 & & & 0,14 & & & & 0,14 & & & & 0,59 & $* *$ \\
\hline
\end{tabular}

VB - visina biljke; Br.L - broj listova; D9L - duljina 9. lista; ŠgL - širina 9. lista; P9L - površina 9. lista; Š/D -omjer širine i duljine lista; *signifikantno kod P<0.05 ** signifikantno kod $\mathrm{P}<0.01$; ns - nije signifikantno

PH - plant height; No.L - number of leaves; $L 9 L$ - length of the $9^{\text {th }}$ leaf; W9L - width of the $9^{\text {th }}$ leaf; $A 9 L$ - area of the $9^{\text {th }}$ leaf; W/L - width to length ratio; ${ }^{*}$ significant at $P<0.05 ;{ }^{*}$ significant at $P<0.01 ;$ ns-not significant

\section{ZAKLJUČAK}

$\mathrm{U}$ ovome radu nisu utvrđene signifikantne razlike $u$ agronomskim svojstvima prinosu, cijeni niti vrijednosti između dviju primijenjenih količina dušičnog gnojiva, 30 i $45 \mathrm{~kg} / \mathrm{ha}$. Ipak, signifikantno povećanje vrijednosti komponenata prinosa kod gnojidbe s $45 \mathrm{~kg} \mathrm{~N} / \mathrm{ha}$, u usporedbi $s$ gnojidbom s $30 \mathrm{~kg} \mathrm{~N} / \mathrm{ha}$, upućuje na višu razinu gnojidbe kao jamstvo osiguranja visokih i stabilnih prinosa $\dot{i}$ te kvalitete osušenoga lista. Usto, viša razina gnojidbe može osigurati sigurne prinose u vlažnim godinama, kada postoji opasnost od ispiranja dušika naročito na lakim pjeskovitim tlima. Tip korištenoga dušičnog gnojiva nije imao signifikantan učinak niti na jedno ispitivano svojstvo. Uzorak korelacija između morfoloških i agronomskih svojstava bio je pod utjecajem okoline, kao i razine gnojidbe, pri čemu su nešto jače korelacije morfoloških svojstava i prinosa utvrđene kod više razine gnojidbe, a cijene kod niže razine gnojidbe. Ipak, većina signifikantnih korelacija prisutna je kod gnojidbe od 45 $\mathrm{kg} \mathrm{N} / \mathrm{ha}$, što dodatno ide u prilog višoj razini gnojidbe kao poželjnome standardu kako u procesu oplemenjivanja tako i u komercijalnoj proizvodnji duhana.

\section{LITERATURA}

1. Budimir, A., Bukan, M., Boić, M., Šarčević, H., \& Kozumplik, V. (2008). Response of flue cured tobacco to reduce fertilization. Cereal Research Communications, 36(S), 1531-1534.

2. Bukan, M., Šarčević, H., Budimir, A., Boić, M., Lewis, R. S., \& Kozumplik, V. (2013). Performance and correlations for agronomic and morphological characteristics of the flue-cured tobacco cultivars. Agriculturae Conspectus Scientifics 75, 27-31.

https://doi.org/10.2135/cropsci2012.03.0173

3. Cristanini, G. (2006). Aromatic Virginia Tobacco: A Responsible and Competitive Production. Arvan, Mira, Venezia, Italy.

4. Drake, M. P., Vann, M. C., \& Fisher, L. R. (2015) Nitrogen application rate influence on yield, quality, and chemical constituents of flue-cured tobacco, part I: application timing. Tobacco Science 52, 11-17. https://doi.org/10.3381/14-041R.1

5. Hawks, S. N., \& Collins, W. K. (1983). Principles of flue-cured tobacco production (1st ed.). Raleigh, N.C., USA

6. Maleki, H. H. (2011). Correlation and sequential path analysis of some agronomic traits in tobacco (Nicotiana 
tabaccum L.) to improve dry leaf yield. Australian Journal of Crop Science, 5(12): 1644-1648.

7. Marchetti, R., Castelli, F., \& Contillo, R. (2006). Nitrogen requirements for flue-cured tobacco. Agronomy Journal, 98(3), 666-674.

https://doi.org/10.2134/agronj2005.0105

8. Pacheco, A., Rodríguez, F., Alvarado, G., \& Burgueño, J. (2017). "ADEL-R". Analysis and design of experiments with $\mathrm{R}$ for Windows. Version 2.0", hdl:11529/10857, CIMMYT Research Data \& Software Repository Network, V3.

9. Shah, K. A., Shah, F. L., Ali, A., Rahman, H. U., Yahya, M. \& Rahman, A. U. (2016). Phenotypic and genotypic correlation for leaf and quality characters in flue cured Virginia tobacco. International Journal of Biosciences, 8(5): 175-181.

https://doi.org/10.12692/ijb/8.5.175-181

10. Sisson,V. A., Rufty, T. W., \& Williamson, R. E. (1991). Nitrogen-use efficiency among flue-cured tobacco genotypes. Crop Science 31(6), 1615-1620. https://doi.org/10.2135/cropsci1991.0011183X003100060047x
11. Šarčević, H., Gunjača, J., Budimir, A., Boić, M., Bolarić, S., Bukan, M., Lewis, R. S. \& Kozumplik, V. (2013). Long-term genetic Improvement and genetic diversity of Croatian flue-cured tobacco (Nicotiana tabacum L.) cultivars. Crop Science, 53(1): 112-120. https://doi.org/10.2135/cropsci2012.03.0173

12. Tso, T. C. (1972). Physiology and Biochemistry of Tobacco Plant. Dowden, Hutchinson and Ross, Stroudsburg, Pennsylvania,USA.

13. Wan Aznran, W. I., \& Salbiah, H. (1989). Effects of nitrogen fertilization rates on yield and quality of fluecured tobacco grown on bris sandy soil in Malaysia. MARDI Research Journal, I7(2): 191-199.

14. White, F. H., Pandeya, R. S. \& Dirks, V. A. 1979. Correlation studies among and between agronomic, chemical, physical and smoke characteristics in flue-cured tobacco (Nicotiana tabacum L.). Canadian Journal of Plant Science, 59(1), 111-120. https://doi.org/10.4141/cjps79-016

15. Zhang, S. J., Huang, Y. J., Ren, O. C., Zhang, X. O., Yang, Z. X., \& Yang, T. Z. (2010.) Effects of nitrogen fertilization on leaf senescence, photosynthetic characteristics, yield, and quality of different flue-cured tobacco varieties. The Journal of Applied Ecology, 21(3): 668-674.

\section{EFFECT OF NITROGEN FERTILIZATION RATE AND TYPE OF NITROGEN FERTILIZER ON AGRONOMIC AND MORPHOLOGICAL TRAITS OF FLUE-CURED TOBACCO}

\section{SUMMARY}

The aim of this study was to determine the effect of nitrogen (N) fertilization rate of 30 and $45 \mathrm{~N} \mathrm{~kg} / \mathrm{ha}$, as well as three commercial $N$ fertilizers, $\mathrm{CaNO}_{3}\left(15 \%\right.$ N), KAN (27\% N) and YaraMila ${ }^{T M}$ Cropcare (8:11:23) on the agronomic traits: yield, price, and value, as well as six morphological traits of flue-cured tobacco. The field experiments, which included three Croatian tobacco cultivars, were conducted in four environments. Nitrogen fertilization had a significant effect only on yield components: length, width and area of the $9^{\text {th }}$ leaf, whose values for fertilization with $45 \mathrm{~kg} \mathrm{~N} / \mathrm{ha}$ were $2.2 \%, 3.5 \%$, and $5.8 \%$ higher, respectively, compared to fertilization with $30 \mathrm{~kg} \mathrm{~N} / \mathrm{ha}$. The type of $\mathrm{N}$ fertilizer did not have a significant effect on any of the traits. The pattern of correlations between morphological and economic traits was influenced by the environment, as well as by the level of fertilization. Although no effect of fertilization level on economic traits was found, the significant increase in yield components at $45 \mathrm{~kg} \mathrm{~N} / \mathrm{ha}$ compared to $30 \mathrm{~kg} \mathrm{~N} / \mathrm{ha}$ suggests a higher level of fertilization as a guarantee of ensuring high and stable yields and quality of the cured leaf.

Keywords: flue-cured tobacco, nitrogen, fertilization, yield, quality

(Primljeno 19. kolovoza 2019.; prihvaćeno 21. listopada 2019. - Received on August19, 2019; accepted on October 21, 2019) 